\title{
Disclosure of Provisions for Decommissioning Costs in Annual Reports of Oil and Gas Companies: A Content Analysis and Stakeholder Views
}

\section{Professor Hafez Abdo (Corresponding Author)}

Nottingham Trent University

Nottingham Business School, 50 Shakespeare Street, Nottingham, NG1 4FQ

Email: h.abdo@shu.ac.uk

ORCiD: orcid.org/0000-0001-9279-0035

Linkdin: https://www.linkedin.com/in/dr-hafez-abdo-29580758/

\section{Professor Musa Mangena}

University of Essex

Essex Business School, Wivenhoe Park, Colchester CO4 3SQ

Tel: +44 (0) 1206873428

Email:mm17456@essex.ac.uk

ORCiD: orcid.org/0000-0002-3005-8110

Linkdin: https://www.linkedin.com/in/professor-musa-mangena-22192416/

Mr Graham Needham

Nottingham Business School

50 Shakespeare Street, Nottingham, NG1 4FQ

Tel: +44 (0)115 8483850

Email: graham.needham02@ntu.ac.uk

Linkdin: https://www.linkedin.com/in/graham-needham-30092b118/

\section{Mr David Hunt}

Former visiting professor at Nottingham Business School

28 Elm Close, Mapperley Park

Nottingham NG3 5AH, United Kingdom

Tel: +44 (0) 1159609937

Email: david.m.hunt@ntlworld.com

Tel: 07785384846

Linkdin: https://www.linkedin.com/in/david-hunt-2a52267/

\begin{abstract}
This study examines the extent of compliance with accounting disclosure requirements relating to provisions for decommissioning costs by oil and gas companies. We also investigate the views of stakeholders on the reporting practices of these companies. Using a content analysis approach, our findings reveal that compliance is substantially high, but companies tend to take a tick-box approach providing only minimum disclosure requirements. In semi-structured interviews, we find that disclosure decisions were driven by concerns about the credibility of information due to complexities in the accounting processes, regulatory requirements, lack of information demand and proprietary costs. These findings have policy implications.
\end{abstract}

Key words: Disclosure decisions; Compliance; Decommissioning costs; Factors of disclosure; International accounting standards, Oil and gas sector 
Highlights

- IASs/IFRSs provide a suitable basis for accounting and reporting for decommissioning costs

- Compliance of oil and gas companies with disclosure requirements is substantially high but lacks sufficient details

- Disclosure decisions of oil and gas companies are affected by credibility concerns, regulatory requirements and proprietary costs 


\section{Introduction}

In this study, we examine disclosure practices relating to provisions for decommissioning costs by oil and gas companies listed on the London Stock Exchange (LSE). Oil and gas companies have obligations to dismantle, remove and restore items of property, plant and equipment (PPE) at the end of their offshore and onshore operations and to remediate to agreed standards any environmental damage they may have caused (Hamzah, 2003; Standard and Poor's, 2007; PwC, 2008; Gosling, 2017). These obligations are referred to as decommissioning. ${ }^{1}$ According to Standard and Poor's (2007) and Rogers and Atkins (2015), the cost obligations for decommissioning are estimated to be equal to half of the oil and gas industry's total debt. Similarly, with a focus on the North Sea alone, a report by the UK Oil and Gas Authority (2018) estimated decommissioning costs of all infrastructures at about $£ 59.7$ billion. Hence, the magnitude of decommissioning cost obligations in the oil and gas industry is substantial and is attracting significant attention from regulatory authorities and others (see Standard and Poor's, 2007; Rogers and Atkins, 2015; Monciardini, 2016, UK Oil and Gas Authority, 2018).

A major problem relating to decommissioning is that, whereas the obligation to decommission assets arises at the time the oil and gas assets are installed, the actual decommissioning activities are undertaken at the end of the productive life of the oil and gas assets (Khurana et al., 2001; Hamzah, 2003; Parente et al., 2006; Rogers and Atkins, 2015). This means that the actual decommissioning costs are only incurred by the company when the assets are no longer generating revenue, which could be several years after their first installation. It is in this context that existing accounting standards require oil and gas companies to make provisions for decommissioning costs from the installation stage of the assets and to review these annually. The rationale for requiring these provisions is to ensure that adequate funds are set aside by oil and gas companies to meet such large and mounting future obligations (Luther, 1996). This is critical because inadequate funding could have substantial consequences for a company's cash flows and survival (Khurana et al., 2001). In particular, since the relevant oil and gas assets are no longer productive, the company would have to fund the decommissioning costs from other revenue generating projects or from selling its productive assets. At the extreme, if a company fails to meet the unfunded costs from its revenue generating projects or disposal of its assets, the burden might have to be met by the taxpayer to ensure that the environment is remediated (Hamzah, 2003; Parente et al., 2006; Falconer and Wicks, 2016).

${ }^{1}$ Decommissioning is defined in the Statement of Recommended Practice (OIAC. SORP, 2001) as "the process of plugging and abandoning wells, of dismantlement of wellhead, production and transport facilities and of restoration of producing areas in accordance with licence requirements and the relevant legislation" (para 88). 
Hence, the potential impact resulting from unfunded decommissioning costs could be enormous, not only to investors, but also to the wider stakeholders.

Given the estimated magnitude of the decommissioning obligations, coupled with the potential consequences of any funding gaps, attention has been directed towards the need for oil and gas companies to improve the disclosure of information about these obligations in their annual reports (see Standard and Poor's, 2007; Rogers and Atkins, 2015; Monciardini, 2016). The disclosure of these obligations by oil and gas companies is even more important in the context of increasing concerns about protecting the environment globally. Oil and gas companies, by the nature of their business, have a substantial impact on the environment, thus providing information about their operations is critical to stakeholders. In this regard, investors would be interested in information about decommissioning costs to help them to understand the risks posed by these obligations to the company's future cash flows, particularly when they make decisions about share valuation (Barth et al., 2008). As shown by prior literature, for example, D'Souza et al., (2000), Boatsman et al. (2000) and Khurana et al. (2001), information about decommissioning cost provisions have share valuation relevance, that is, investors use this information. Other stakeholders such as environmental groups and the public in general would also be interested in this information as it will allow them to make informed judgements about the ability of the company to clean up the environmental damage, as well as to understand the potential impact on the taxpayer in the event that the company fails to honour obligations to decommission. The interest in this information by environmental groups and the public is exemplified in the case of Brent Spar where, the environmental group, Greenpeace, worked with the public and civil society to stop Shell plc from dumping its end-of-life assets in the North Sea (see Hamzah, 2003). In addition, to the extent that the taxpayer takes responsibility to remedy the environmental damage in the event that the company fails to pay the costs (Parente et al., 2006; Falconer and Wicks, 2016), both regulators and taxpayers would have a strong interest in the disclosures. This is in order to be able to satisfy themselves that companies are making appropriate plans to meet the obligations when they fall due.

The accounting and reporting of the provisions for decommissioning costs are dealt with under IAS16 (Property, Plant and Equipment: PPE) and IAS37 (Provisions, Contingent Liabilities and Contingent Assets). However, a major challenge for oil and gas companies, according to Abrahamson (2014), Rogers and Atkins (2015) and HMRC (2016), is that accounting for these costs is marred by substantial complexities and uncertainties. These derive from the timing, cost estimation, technological development, changes in oil prices, currency movements as well as changes to regulatory and tax regimes. Khurana et al. (2001) suggest 
that these complexities and uncertainties are likely to impede full disclosure of provisions for decommissioning costs by oil and gas companies due to concerns about the credibility of the information. This raises questions about whether oil and gas companies disclose sufficient information, specifically, to comply with the reporting requirements of IASs. Oddly, with the exception of Russell et al. (1998) and Rogers and Atkins (2015), there are no other studies examining the reporting practices of oil and gas companies relating to provisions for decommissioning costs. Even then, Russell et al. (1998) and Rogers and Atkins (2015) are only descriptive and do not provide an understanding of the reasons for the reporting practices. In addition, these studies examine compliance with Statement of Recommendaed Practice (SORP) and Securities and Exchange Commission (SEC) requirements, respectively, but not with IAS/IFRS disclosure requirements, which have been adopted by the majority of countries since 2005. In this study, we extend these two studies by addressing three research questions:

1- To what extent do oil and gas companies listed on the London Stock Exchange (LSE) comply with the disclosure requirements of the International Accounting Standards relating to provisions for decommissioning costs? ${ }^{2}$

2- To what extent are the complexities and uncertainties in accounting for provisions for decommissioning costs perceived by selected key stakeholders as affecting the decisions of oil and gas companies to disclose such information in their annual reports?

3- What other factors are perceived by selected key stakeholders to be influencing oil and gas companies' disclosure decisions relating to the provisions for decommissioning costs?

Using a mixed methods approach, involving a content analysis of annual reports and interviews with selected key stakeholders (i.e., oil and gas companies, regulators, oil and gas consultants, academics, oil and gas expert auditors), we report a number of findings. ${ }^{3}$ We find that the level of compliance with most of the disclosure requirements of IASs on decommissioning costs is substantially high. However, some companies tended to provide the very minimum required information in their annual reports. For example, in many cases, a single numerical figure for provisions for decommissioning costs was provided with no extra

\footnotetext{
${ }^{2}$ The London Stock Exchange is divided into two markets: the Main Market and the Alternative Investment Market (AIM). The main market lists large and more mature or established companies, while the AIM is the market for smaller and growing companies with limited history. Our study sample of oil and gas companies is drawn from both markets.

${ }^{3}$ Our original intention was to also include investors as one of the key stakeholders. However, we were unable to identify investors with an interest in the oil and gas sector to interview for this study. Hence, the findings reported in this study do not include the perception of investors.
} 
detail to aid understanding in terms of field, geographical location or timing of decommissioning. We also found a general consensus among the stakeholders that the existing IASs are adequate and provide a good basis for the reporting of provisions for decommissioning costs. However, due to the absence of historical precedents on the accounting treatment and reporting of decommissioning cost items, oil and gas companies want to see more guidance from accounting standard setters on both accounting and reporting of these costs. Further, we identify a number of factors that influence the disclosure practices of oil and gas companies. In particular, stakeholders identified the complex and uncertain processes in accounting for the provisions for decommissioning costs as creating a disincentive for companies to report the information. Specifically, the process of estimating costs and provisions was considered complex and uncertain, and too subjective, thus raising major concerns about the credibility of the resultant information and its use by stakeholders. Regulatory requirements (i.e., requirements of IASs 16 and 37) came out as driving disclosure by oil and gas companies, with companies only meeting the minimum requirements with little or no extra disclosures. Our findings also show that companies are not forthcoming with disclosures because they perceived external demand for the information as non-existent. Given this, it appears that the disclosure of provisions for decommissioning costs is not influenced by the desire to reduce agency-related costs or by any incentives to signal the quality of the company, with the expectation of reducing the cost of capital. Finally, disclosure decisions are influenced by proprietary costs. In particular, companies were concerned about competitive disadvantage, information misinterpretation by users and increased public scrutiny.

Our study contributes to the literature and practice in a number of ways. Firstly, we add to the works of Russell et al. (1998) and Rogers and Atkins (2015). Whereas Russell et al. (1998) and Rogers and Atkins (2015) examine SORP or SEC requirements, respectively, we investigate compliance with IASs/IFRSs and also we consider international companies instead of just UK or US companies. Secondly, we provide evidence about the perceptions of selected stakeholders (i.e., companies, regulators, consultants, auditors and academics) on reporting practices relating to decommissioning costs and the factors perceived as influencing reporting practices. In this respect, in line with prior literature (e.g., Gibbins et al., 1990 and Luther, 1996), we find that disclosure decisions are influenced by regulation, external demand for information and proprietary costs. More importantly, we offer one of the first pieces of evidence showing that complexities and uncertainties in accounting for decommission costs affect disclosure decisions by oil and gas companies. Thirdly, we extend the existing literature by examining compliance with IAS/IFRS in contexts where IAS/IFRS are voluntary (e.g., Street 
and Gray, 2001; Glaum and Street, 2003; Glaum et al., 2013) to a mandatory regulatory setting. Whereas the prior literature shows limited compliance, our work demonstrates high compliance, but no extra disclosure beyond requirements. Fourthly, we focus on specific accounting standards dealing with provisions for decommissioning costs, an important issue for the oil and gas sector, regulators, investor and other stakeholders (see Abrahamson, 2014; Rogers and Atkins, 2015; HMRC, 2016). Finally, our work provides evidence that is of value to policy-makers and practitioners with interest in enhancing the disclosure of decommissioning costs information and compliance with IAS/IFRSs.

The remainder of this paper is organised as follows. Section 2 discusses the regulation and accounting for provisions for decommissioning costs. In Section 3, the literature is reviewed, and in Section 4, the research design is presented. Section 5 presents and discusses the findings. Finally, we provide a conclusion in section 6.

\section{Regulation of accounting for and reporting of decommissioning costs}

The oil and gas industry is international in nature and, therefore, subject to international regulations and laws which require the sector to decommission assets at the end of their production life (Techera and Chandler, 2015). The requirement to decommission oil and gas assets are dealt with by a number of international treaties including the 1958 Geneva Convention on the Continental Shelf, the 1982 United Nations Convention on Law of Sea (UNCLOS) and the 1989 International Maritime Organization (IMO) Guidelines and Standards. However, these international treaties do not address accounting and reporting issues relating to decommissioning costs.

The accounting and reporting of provisions for decommissioning costs are dealt with under different countries' local accounting standards or IAS/IFRS. In the context of companies listed on the LSE, however, the oil and gas companies are required by the UK Listing Authority to comply with the measurement and disclosure requirements of IAS/IFRS. The specific accounting standards dealing with the accounting treatment for, and disclosure of, decommissioning costs are IAS16 (Property, Plant and Equipment: PPE) and IAS37 (Provisions, Contingent Liabilities and Contingent Assets). Additional guidance is provided in IFRIC 1 Changes in Existing Decommissioning, Restoration and Similar Liabilities. IAS16 states that 'an item of property, plant and equipment that qualifies for recognition as an asset shall be measured at its cost' and the components of such cost are 'purchase price, directly attributable costs and initial estimate of the costs of dismantling and removing the item or 
restoring the site on which it is located' (IAS16, 2001, para 16). Thus, at the time of installation of an oil and gas asset, the company is required to estimate the cost of decommissioning that asset. To this extent, the installation of the oil and gas assets gives rise to liabilities or obligations for decommissioning the assets. According to IAS37, a liability or an obligation exists when the company has no other alternative but to sacrifice economic benefits to settle the obligation or liability (IAS37, 2014). Since oil and gas companies are required by law to decommission their installations at the end of their productive capacity, the costs of decommissioning meet the definition of a liability under IAS37. Therefore, the estimated decommissioning costs, measured on a present value basis, are to be capitalised into the cost of the installation of the oil and gas asset as required by IAS16. The total cost of the asset, including the provisions for decommissioning costs, are to be depreciated over the useful life of the field. Thus, oil and gas companies are required to estimate decommissioning costs and, to create and fully recognise the provision on the balance sheet.

In terms of reporting, listed firms must comply with the reporting requirements of IAS16 and IAS37 as required by the listing rules of the LSE. Under IAS16, companies are required to disclose the measurement bases used, the depreciation method used and the useful lives of the assets. Additionally, the gross carrying amount of assets at the beginning and the end of the period, showing additions, disposal, revaluations, depreciation, impairments losses and any other movements are also to be disclosed (Melville, 2011; Picker et al., 2016). The decommissioning costs form part of an oil and gas structure's total costs. However, revaluation of decommissioning costs impacts the PPE total costs and therefore needs to be disclosed when taking place. With regard to IAS37, disclosure is required of: the carrying amount of provisions for decommissioning costs at the beginning and end of each financial period; additional provisions made during the period; amount of provisions used or removed during the period; a brief description of the nature of the obligation; the expected timing of any resulting expenditure; and an identification of involved uncertainties (Melville, 2011). The disclosure requirements of these two standards, together with IFRIC 1 guidance, have been used to construct a disclosure index (see Appendix 1 for details).

\section{Literature review}

\subsection{Theory}

According to Barth et al. (2008), IAS/IFRS are high quality standards and lead to quality information that is helpful to users in making economic decisions. The authors add, however, 
that the extent to which high quality information is achievable under IAS/IFRS depends upon whether companies comply with the requirements. In theory, for listed companies, universal compliance with IAS/IFRS would be expected because failure to comply attracts penalties from listing authorities (Robinson et al., 2011) and the stock market via an increase in the cost of capital (Verrecchia, 1990; Lambert et al., 2007). However, as pointed out by Robinson et al. (2011), this is only feasible if the authorities and the stock market can objectively assess noncompliance with reporting requirements. Given the complexities and uncertainties associated with the accounting for decommissioning cost provisions (see Abrahamson, 2014; Rogers and Atkins, 2015), policing of these disclosures might be difficult and costly. To the extent that listing authorities and the stock market are unable to effectively police compliance with disclosure requirements, oil and gas companies have discretion over what and how much information about provisions for decommissioning costs they disclose. Such decisions to disclose information involve a trade-off between benefits and costs of disclosure (see Coles et al., 1995; Lambert et al., 2007). If the benefits outweigh the costs, oil and gas companies are more likely to comply with IAS/IFRS requirements and, possibly, provide more details than required by accounting standards and/or regulations. A number of theories have been applied in the literature to explain disclosure decisions, including agency theory, signalling theory, stakeholder theory and proprietary cost theory.

Both the agency theory (Jensen and Meckling, 1976) and signalling theory (Hughes, 1986) suggest that companies disclose information to reduce information asymmetries between the company and its stakeholders, particularly the existing and potential shareholders. Specifically, the agency theory posits that disclosure reduces agency-related costs between shareholders and the management (Luther, 1996). In particular, it helps shareholders understand the operations and performance of the company, thereby enhancing their ability to monitor the actions and performance of the management. Similarly, signalling theory asserts that disclosure is a signal to the stock market about the quality of the company (Hughes, 1986) that helps to attract more investors, improving liquidity of the shares and consequently lowering the cost of capital (Coles et al., 1995; Lambert et al., 2007; Cuadrado-Ballesteros et al., 2016). The underpinning assumption of this theory is that investors value more disclosure and companies have incentives to minimise the cost of capital. In this context, companies with positive information (i.e. good news) would disclose more information to signal their quality to the capital market. Even companies with unfavourable information will have incentives to provide detailed information to reduce the probability of being considered 'a lemon' by investors (Akerlof, 1970). That is, failure to disclose might lead investors to perceive the company as 
withholding information that would reveal the worst and, hence, demand a lower price for the company's shares. More disclosures provide an opportunity for the company to explain the unfavourable information and help to reduce the potential negative investor perception about its quality. Thus, based on these theories, oil and gas companies will provide decommissioning costs disclosures to lower information asymmetry between the companies and investors.

Decisions to disclose information about provisions for decommissioning costs can also be explained using the stakeholder theory (Freeman, 1984; Mitchell et al., 1997). The theory argues that a company is a 'nexus of contracts' amongst a wide range of stakeholders and that these stakeholders have legitimate interests about the operations of the company. In this regard, in addition to investors, oil and gas companies' other stakeholders, regulators, environmental activists groups, civil society and the public in general, may all be concerned about the decommissioning of oil and gas assets and the company's ability to undertake such obligations. This is particularly relevant for oil and gas companies given that their operations have a substantial impact on the environment and the society. To the extent that information about decommissioning costs helps these stakeholders assess the company's ability to meet its obligation to decommission the assets with minimum environmental damage, oil and gas companies would be expected to disclose the information. Disclosing the information might help reduce stakeholder concerns, leading to less scrutiny of the company's operations and improving the company's reputation in the public's eye.

Finally, proprietary cost theory (Dye, 1986; Verrecchia, 1990) can also be used to understand oil and gas companies' reporting of information about provisions for decommissioning costs. This theory asserts that companies consider proprietary costs in making decisions about disclosure. These costs, in addition to the costs of developing and presenting the information, include competitive position costs and the potential that the information could be misinterpreted by the users and public scrutiny. First, if provisions for decommissioning costs are reflective of the additional investments for an oil and gas field, such information may aid competitors in assessing the attractiveness of a particular field or location. This may lead to new entrants into the particular oil and gas field with implications for the existing operators (Ellis et al., 2012). A second cost is rooted in the ability of investors and other stakeholders to process information (e.g., Kim and Verrecchia, 1994; Coller and Yohn, 1997). Since accounting for decommissioning costs, particularly the estimation of the costs, is complex and uncertain, the information may also be difficult for users to process and interpret. For example, high estimates of provisions for decommissioning costs may be perceived by investors and other stakeholders as indicating the actual costs of decommissioning. This may lead the investors and 
other interested stakeholders to assess otherwise profitable oil and gas assets as inefficient, based on an assessment of the provisions for decommissioning costs, particularly in periods of low oil and gas prices. This has implications for: (i) an investor's valuation of the company's shares, and, consequently, its cost of capital (Lee et al., 1993); (ii) other stakeholders' perception of the company's ability to decommission the assets, leading to increased public scrutiny (Li et al., 1997). If these proprietary costs outweigh the benefits of disclosure of provisions for decommissioning costs, companies may not commit to providing the information.

\subsection{Related studies}

Our work relates to two streams of prior studies. The first stream of studies examines compliance with IAS in different contextual settings such as Australia (Tower et al., 1999), Germany (Glaum and Street, 2003; Glaum et al., 2013), Switzerland (Street and Gray, 2001), Gulf Co-operation states (Al-Shammari et al., 2008) and cross-country (Hodgdon et al., 2009). With the exception of Al-Shammari et al. (2008), these studies find substantial non-compliance with IASs and this could be due to the non-mandatory nature of IASs at the time. Al-Shammari et al. (2008) show increasing compliance with IASs since most stock exchanges started mandating adoption of IAS/IFRS in 2005. We differ from these studies in three main ways. Firstly, whereas all these prior studies examine compliance with several IASs addressing different disclosure issues, we take a different approach by focusing on a specific important, but rarely examined disclosure issue - provisions for decommissioning costs in the oil and gas sector. As noted earlier, the mounting decommissioning costs in the sector makes their disclosure important to aid stakeholders in making decisions. Secondly, we focus on companies listed on the LSE, a setting in which compliance with the IAS/IFRS is mandatory, so that the expectation is that compliance will be high. Thirdly and most importantly, instead of only relying on content analysis of annual reports, we also investigate stakeholder views on reporting practices relating to provisions for decommissioning costs and the factors perceived as influencing such practices.

The second stream of studies related to our study focuses on accounting disclosures by oil and gas companies, but has been limited to the disclosure of oil and gas reserves. This stream of studies has examined the determinants of oil and gas reserves disclosures (e.g., Malone et al., 1993; Berry and Wright, 2001; McChlery et al., 2015). None of these consider provisions for decommissioning costs. Only two studies have investigated the reporting of decommissioning costs by oil and gas companies. Russell et al. (1998) studied the state of 
accounting for the cost of abandoning North Sea oil and gas fields and showed that UK oil and gas companies exercised a high level of compliance with the regulations governing accounting for the cost of abandoning North Sea oil and gas fields as embedded in SORP. Rogers and Atkins (2015) analysed compliance of 146 US listed oil and gas companies with Assets Retirement Obligations (AROs) disclosure requirements of Statement of Financial Accounting Standard 143. They concluded that there is poor adherence by oil and gas companies to the AROs disclosure requirements. While these two studies provide some insights, they have not considered compliance with IAS/IFRS disclosure requirements for provisions for decommissioning costs. Further, these studies are only based on publicly available data and do not examine the views of stakeholders on company disclosure practices. They also do not investigate the factors affecting the disclosure practices. Our study addresses these issues.

\section{Research Design}

We employ a two-staged research approach to address our research questions. In the first stage, we content analyse annual reports of oil and gas companies listed on the London Stock Exchange, both the Main Market and the Alternative Investment Market (AIM). We identify 12 oil and gas companies from the Main Market and 110 companies from the AIM. We eliminate three companies from the Main Market and 11 companies from the AIM because they are not exploration and production companies. We eliminate a further 40 companies because they are at the start-up stage with no revenues and, thus, had no provisions for decommissioning costs to disclose. The resultant sample for the study is 68 companies and includes companies from different countries, thus representing a wide diversity in geographical location of operations (see Table 1).

\section{Insert Table 1 about here}

For each of the sample companies, we collect the latest annual reports published in the period 2014 and 2015 from the company's websites. To measure the level of compliance with the reporting requirements of IAS/IFRS relating to the provisions for decommissioning costs, we applied the content analysis method. Content analysis has been extensively used in previous disclosure studies (e.g., Mangena and Pike, 2005; Hodgdon et al., 2009; Abdo and Al Drugi, 2012; Al Drugi and Abdo, 2014). We first developed a checklist of provisions for decommissioning cost disclosures as required by IAS16, IAS37 and IFRIC 1. This process identified 17 required items relating to disclosure of decommissioning costs (see Appendix 1). 
We then read the annual reports, in particular the financial statements, accounting policies and notes to the accounts to identify the information items. Each item was scored using a dichotomous scoring approach, where a score of 1 is awarded if disclosed and 0 otherwise. ${ }^{4} \mathrm{We}$ then constructed a disclosure compliance index for each company by dividing the total number of items reported in the annual report with the total number of items applicable to the company. This process was done by one researcher, but to ensure that the scores are reliable, a second researcher independently scored a selection of the annual reports, and the resulting scores were similar to those of the first researcher.

In the second stage of the research, we carried out semi-structured interviews in order to garner the perceptions of oil and gas companies and other stakeholders on reporting practices relating to the provisions for decommissioning costs. This stage was designed to provide a better understanding of the compliance scores developed in stage 1 as well as to explore the factors influencing the reporting of provisions of decommissioning costs by oil and gas companies. Following the advice of Eisenhardt (1989), we sought to identify different stakeholder groups that were knowledgeable and experts on decommissioning and reporting practices to ensure that we could obtain expert views. In this regard, we wrote to the listed oil and gas companies used in the first phase of our study. We also contacted the UK Oil\&Gas Authority (OGA), the Department for Business, Energy and Industrial Strategy (DBEIS), academics, consultants, external auditors and investors. In total, 13 stakeholders agreed to participate in the semi-structured interviews. These were senior people in their organisations and included group accountants or finance officers from oil and gas companies; regulatory officers from the OGA and the DBEIS; external auditors specialising in the audit of oil and gas companies; independent oil and gas consultants; and expert academics at UK higher education institutions. However, none of the investors we contacted responded to our requests for interviews. The list of interviewees and the length of each interview are as in Table 2.

\section{Insert Table 2 about here}

In developing the interview guide, we considered the findings of the content analysis phase of the study as well as the disclosure literature. The interview guide addressed three main issues: the perceived importance of decommissioning cost information to stakeholders and its

\footnotetext{
${ }^{4}$ Our scoring approach does not capture the importance of the disclosure items. It is possible that the decisions to report is based on the perceived importance of the item, that is, companies disclose information items that they believe are important. However, Mangena and Pike (2005) examined disclosure on the basis of the importance of the items based on the perception of users of information. They find no significant difference between the two measures and concluded that companies disclose important information items as much as they do information that is perceived as less important.
} 
disclosure in the annual report; the accounting for provisions of decommissioning costs and impact on reporting practices; and factors affecting reporting of information about provisions for decommissioning costs. The semi-structured interviews took place between May and June 2016 and ranged from 22 to 60 minutes. To ensure consistency throughout, all interviews were conducted by one researcher. They were all audio recorded and then transcribed by the researchers. Where relevant, follow-ups were made to clarify the responses.

\section{Findings and Discussion}

In this section, we present and discuss our findings, structured around the research questions. Firstly, we discuss the results of the content analysis of annual reports. Secondly, we explore the views of stakeholders on the reporting practices on provisions for decommissioning costs. Thirdly, we draw from the disclosure literature to understand the factors influencing the decisions to disclose information about provisions for decommissioning costs.

\subsection{Compliance with IAS reporting requirements-A content analysis of annual reports}

Our first research question seeks to provide understanding of compliance with the reporting requirements of IAS by oil and gas companies. We address this question by undertaking a content analysis of annual reports. The results are presented in Table 3, Panels A and B.

\section{Insert Table 3 about here}

In Panels A and B, we report summary descriptive statistics of the overall disclosure compliance scores, including the distribution of the scores across ranges. As Panel A indicates, the mean disclosure score is 0.634 , implying that on average, oil and gas companies listed on the LSE comply with about $63.4 \%$ of the information required by the IASs. However, the problem with the overall mean is that it may be influenced by outlier disclosure items, in particular, items that may not necessarily be relevant to the company. Given this, we analyse individual disclosure items and observe that disclosure is substantially lower for items 1 and 12. Both are awarded very low scores (average of below 10\%) compared to others (see table 4 for item by item disclosure scores). These items may unduly influence the level of overall disclosure compliance we are observing. Item 1 concerns disclosure "in the extremely rare cases", for example, where reliable estimate cannot be made. In such cases, IAS37 requires the costs of decommissioning to be treated as a contingent liability. It is possible, many companies may not have these extremely rare cases to disclose. With regard to item 12, "reimbursement of decommissioning costs" is not a common case, therefore it is expected that the compliance score for this item 
would be rather low. Given this reasoning, we eliminate these two items and re-analyse the disclosure compliance scores. The mean overall score improves significantly from $63.4 \%$ to $71.1 \%$ (see Panel A). These statistics present a picture of a high level of compliance with IAS16, IAS 37 and IFRIC 1 disclosure requirements.

In Panel B, we examine the distribution of companies across disclosure compliance score ranges. This analysis is aimed at helping us to understand how companies are distributed across disclosure scores, thus providing additional insights into compliance with requirements. For the scores that include all items (that is, including 1 and 12 noted above), we observe that $20.5 \%$ of the companies provide less than $50 \%$ of the required information, $26.5 \%$ are in the range $50 \%$ to less than $70 \%$ and $53.0 \%$ provide more than $70 \%$ of the information (of which only 2 companies, which is $2.9 \%$, are fully compliant). When we eliminate items 1 and 2 , the number of companies in the $70 \%$ to $100 \%$ disclosure compliance score range increases from $53.0 \%$ to $67.6 \%$ (Panel B) (of which 8 companies, which is $11.8 \%$, are fully compliant).

Taken together, our results suggest that the majority of companies exhibit high compliance with the reporting requirements of IASs on decommissioning cost provisions. However, full compliance is not achieved. Standard and Poor's (2007) and Rogers and Atkins (2015) also show that companies do not fully comply with decommissioning cost disclosure requirements. In addition, and even more important, our analyses show that while compliance appears to be substantially high, some oil and gas companies only provide the very minimum information required, with little or no further details to aid understanding. For example, Empyrean Energy Plc states in its 2015 annual report (note 9, p. 40) that the company has recognised oil and gas decommissioning assets of \$218,000 in 2014 and \$252,000 in 2015. No further explanation is provided. Another example is in the annual report of Rose Petroleum Plc (2015: 36) which states:

The decommissioning provision is calculated as the net present value of the Group's share of the expenditure expected to be incurred at the end of the producing life of the facility in the removal and decommissioning of the production, storage and transportation facilities currently in place.

This implies that decommissioning of upstream and downstream facilities is grouped together in one account. No details of decommissioning of exploration and production facilities is made separately in the accounts or in the notes to the accounts of Rose Petroleum Plc. This practice is consistent with what Collins et al. (1993) refers to as a tick-box approach to compliance with the reporting requirements rather than engaging in the spirit of informative reporting. Therefore, whilst companies appear to comply with disclosure requirements, they are not providing 
detailed information to help stakeholders' understanding and proper assessment of the financial implications of the costs and the ability of the company to meet their future obligations.

We also observe that there are substantial variations in compliance with IAS reporting requirements in the sample of oil and gas companies (measured by the standard deviation, see Table 3, Panel A). We draw from the disclosure literature and examine two possible factors for these variations - company size and ratio of decommissioning costs to total assets. ${ }^{5}$ The results are presented in Table 4, Panels A and B. In Panel A, we compare the results of overall disclosure compliance scores and in Panel B, we analyse disclosure by individual items.

\section{Insert Table 4 about here}

In relation to company size, the literature suggests that agency costs are size-related, with higher agency costs associated with larger companies (Collins et al., 1993; Malone et al., 1993; Mangena and Pike, 2005; McChlery et al., 2015). Large companies are also more visible and likely to be under greater scrutiny by stakeholders. Thus, they would disclose more information to reduce the agency costs and public scrutiny (e.g., Glaum and Street, 2003; Mangena and Pike, 2005; McChlery et al., 2015). In addition, we add that larger companies have resources and information systems to deal with the complexities and uncertainties related to the accounting for provisions for decommissioning costs. This allows them to gather and disclose more information about the provisions. To understand whether disclosure compliance differs by company size, we measure company size using a dummy variable taking 1 if the company is listed on the Main Market and 0 if it is listed on AIM. Main Market-listed companies are generally larger than AIM-listed companies. Using this measure, we run independent t-tests statistics to determine whether there are differences between the two groups. We find that with the exception of items 2, 4 and 13, there are no significant differences between Main Market and AIM listed companies. Thus, on the whole, it appears that the size of a company does not affect compliance with IAS/IFRS disclosure requirements for provisions for decommissioning costs.

The ratio of decommissioning costs to total assets reflects the company's ability to meet its decommissioning obligations from its asset-base (Alciatore et al., 2004). In theory, high ratio companies would have incentives to provide more information about their provisions for

\footnotetext{
${ }^{5}$ We note that the disclosure literature has examined many factors using multiple regressions (e.g., governance factors, firm-specific factors, etc.). However, our aim is to understand compliance with disclosure practices and factors influencing such practices from the stakeholders' perspectives, some of which may be difficult to capture in economic modelling. Given this, we do not undertake extensive statistical tests of these other factors as in prior literature. In addition, our sample size is generally too small to undertake multiple regressions as in prior studies.
} 
decommissioning costs in order to signal to the capital market (Hughes, 1986) that they have adequate funds set aside to meet the high-levels of decommissioning obligations when they become due. This should maintain or improve investor confidence, reducing the negative effects on share prices and reducing the cost of capital (Coles et al., 1995; Lambert et al., 2007). Similarly, from a stakeholder theory perspective (Freeman, 1984), they would comply and/or report more information about their ability to decommission their oil and gas assets with minimum impact to the environment and without recourse to public funds in order to allay concerns of stakeholders. We calculated the ratio of decommissioning costs to total assets using information in the annual reports, and then divided the companies into high and low ratios via the median and conducted independent t-tests (see Table 4). We find no significant difference in the overall compliance score. Similarly, with the exception of items 1, 5, 7 and 8, there are no observable differences for the individual items. However, on the whole, although the differences are not significant, the low ratio oil and gas companies appear to comply slightly more than the high ratio companies (Table 4, Panel B). One possible explanation is that the high ratio companies might be concerned about providing more information on decommissioning costs because such information might be misinterpreted and construed by stakeholders as indicative of future viability problems. That is, stakeholders might evaluate the company as being limited in its ability to meet future decommissioning obligations from its existing assets. This may have implications on the share price and consequently the company's cost of capital. It can also potentially bring increased pressure on the company by stakeholders such as environmental activists groups and regulators to consider decommissioning earlier or to sell the assets to companies that may be considered financially stronger.

\subsection{Stakeholder views relating to reporting of decommissioning information}

In this section, we address our second and third research questions. Research question 2 aims to explore stakeholders' views about the complexities and uncertainties involved in the accounting for provisions for decommissioning costs and the impact they have on reporting practices. Khurana et al. (2001) suggested that complexities and uncertainties are major impediments to the reporting of decommissioning cost information. Research question 3 aims to provide an understanding of the other perceived factors influencing decisions by oil and gas companies to disclose information about provisions for decommissioning costs in annual reports. This research question is underpinned by the disclosure literature (see Healy and Palepu, 2001; Beyer et al., 2010). We present and discuss our findings under three issues-(i) 
importance of the annual report as an avenue for disclosing decommissioning cost information; (ii) accounting complexities and uncertainties; and (iii) factors affecting reporting practices.

\subsubsection{Decommissioning costs information and the annual report}

We started by asking the interviewees about whether they view information about provisions for decommissioning costs as important to their stakeholders and whether the annual report was the appropriate avenue to publish the information. Whilst the literature suggests that the disclosure of information relating to provisions for decommissioning costs in the annual reports is important and useful to users (see Boatsman et al., 2000; D’Souza et al., 2000; Khurana et al., 2001; Alciatore et al., 2004; Monciardini, 2016), no research has examined the views of key stakeholders on this issue. Our interviewees agree that the annual report is the most appropriate media to disclose information about provisions for decommissioning costs and that the information is important to stakeholders. In relation to the annual report as the appropriate avenue, the views are exemplified in comments by two oil and gas company interviewees:

Well, I guess annual reports are the only place for this... Well, may be biased because I'm an accountant, so I can read and understand annual reports.

Group Financial Controller, Oil and Gas company (O\&GI1)

In my opinion, they [Annual Reports] pretty much are at the moment the only source of information about decommissioning costs that is published externally by oil and gas companies. ... you could say that they are very important.

Group Financial Accountant, Oil and Gas company (O\&GI2b)

Other interviewees concurred, but also stated that publishing the information in the annual reports could aid an understanding of the risks to the future cash flows of the company by providing an assessment of the potential impact of these future decommissioning liabilities. This implies, consistent with the literature, that information on provisions for decommissioning costs is of value to users of annual reports (see D'Souza et al., 2000; Khurana et al., 2001; Alciatore et al., 2004; Monciardini, 2016). Given the perceived importance of the information, some of the interviewees, particularly the non-oil and gas companies, went further and raised concerns about the limited information provided by the oil and gas companies. As commented by an academic interviewee (ACA2):

I think, to an end user of the annual report, the more transparent the information, the clearer the information presented, the better view the user has of assessing some of the risks relating to it. I've got to say that the degree of disclosure about decommissioning always seems to be very brief, you never get any information that seems to be particularly useful... I think, the only thing you usually see is the discount rate. 
and a regulator interviewee, a senior accountancy advisor (GOV3) stated:

Well, I think it's actually very important, obviously [that is reporting decommissioning information in annual reports]. Decommissioning is a very significant part of the project costs. You are probably aware that in the North Sea alone, I mean to say, we are talking about tens of billions total decommissioning liability out there. And we do have some very significant and very large developments, ..... So, because of the sheer significance of decommissioning, it is vital, I think, for it to be accurately reported in annual reports and for users of those reports to be fully aware of the situation. So, there are investors, employees, contractors, sub-contractors and indeed government, we all have an interest in decommissioning being reported accurately.

These comments are supportive of the literature calling for more information about provisions for decommissioning costs to be published in the annual report (Boone, 1998; Standard \& Poor's, 2007). The key question is, if key stakeholders, including the oil and gas companies themselves, view decommissioning costs as important for users, and the annual report as the most appropriate avenue for disclosing the information, why is there limited disclosure of the information in the annual reports of the oil and gas companies? We make an attempt to provide an understanding of this in the next two sections.

\subsubsection{Accounting for decommissioning and reporting practices}

As we noted earlier, the literature points to major complexities and uncertainties involved in the accounting for provisions for decommissioning costs (Abrahamson, 2014; Rogers and Atkins, 2015). According to Khurana et al. (2001), such complexities and uncertainties can curtail incentives by oil and gas companies to provide detailed information about these cost provisions. Thus, we explored the views of interviewees on the accounting complexities and uncertainties and analysed how these may impact reporting practices of companies. We started by asking the interviewees for their views regarding the adequacy of existing accounting standards dealing with the accounting and reporting of provisions for decommissioning costs.

The interviewees expressed awareness of IAS16, IAS37 and IFRIC 1 and were of the view that these standards provided a good basis for dealing with the accounting and reporting of provisions for decommissioning costs. They certainly did not advocate new accounting standards to deal with decommissioning costs. However, there was a general consensus that more guidance was needed on the application of the accounting standards in areas of difficulties. This need for guidance derives from the fact that decommissioning is a relatively immature activity (Royal Dutch Shell Oil, Annual Report, 2015, p110), thus precedents against which to benchmark accounting treatments for many of the items are non-existent. This creates 
difficulties for companies in accounting for, and therefore reporting of information on provisions for decommissioning costs. For example, highlighting the difficulties in the accounting treatment of decommissioning some assets, an interviewee from an oil and gas company commented:

I think a pipeline bypass for example, one of our assets is being used as a pumping station, and we had to bypass it in order to decommission it. Is that an operating expenditure, or is it a capital expenditure?

Integrated Planning and Appraisal Lead, Oil and Gas Company (O\&GI3)

Others concurred and directly pointed to their reliance on guidance provided by IFRIC 1 in the application of IAS16 and IAS37 to account for provisions for decommissioning costs. This is shown in the quotes from two oil and gas company interviewees who commented:

There isn't a separate standard called accounting for decommissioning costs, and IAS16 is not all that clear insofar as it relates to these costs... obviously, if it was that clear, they would never have needed to issue IFRIC1. We basically go on our interpretation of IASI6, IAS37, and IFRIC1, what they say to do, and IFRIC1 in particular.

Group Financial Accountant, oil and Gas company (O\&GI2b)

and;

The IFRS can't encompass every single possible item, but we still need interpretation and judgement to pick up the various parts of guidance that you see, and reach your reasoned conclusion, which then you would test the acceptance.

Group Financial Controller, Oil and Gas Company (O\&GI1)

These views demonstrate some of the difficulties that oil and gas companies experience in the application of IAS16 and IAS37. Potentially, these difficulties can lead to different outcomes. Firstly, different accounting treatments and reporting may arise across oil and gas companies, thus defeating the attempt to improve comparability. Secondly, and most importantly, they may create disincentives to report the information due to concerns about the credibility or the quality of the information. As suggested by Beyer et al. (2010), managers are often reluctant to release information that might turn out to be incorrect as the market judges them accordingly, with consequences for the company's share valuation and cost of capital.

The concern about credibility of the information is particularly evident when interviewees talk about the nature of decommissioning, which they view as extremely complex. A number of important points were expressed in this context, all of which have implications for reporting practice. The first complex issue relates to the accountants' difficulties in understanding decommissioning terminologies and activities. This, in the view of the interviewees, makes it 
difficult to translate the information into credible cost estimates for publication in the annual reports. This point is exemplified in the following quote:

..There are high pressure, high temperature wells, so for me as an accountant, say how much would it be to decommission this, I would need to go to university and study radio bioengineering, other engineering, to be able to really understand the process and the costs to decommission our plants. And so, the actual costs that go in, I have to absolutely rely on a technical expert to help me with that.

Deputy Chief Finance Officer, Oil and Gas Company (O\&GI5).

This was also raised by an expert academic with extensive experience in the oil and gas sector (ACA1), who states:

My impression is that it's very difficult [accounting for decommissioning costs]. When I talk to accountants, and largely the accountants I talk to on my training, I get the impression that they are not primarily responsible for gathering information. I think they are processing information. I don't think they are actually going out and talking to consultants or contractors about the cost of doing it. I think it's probably quite difficult for them to do.

The second complex issue raised by interviewees is the estimation of the decommissioning costs. The interviewees pointed out that, unlike other assets, the estimates are, in the main, too subjective and complicated because there are too many variables that have to be considered when arriving at an estimate. This makes the process costly to undertake. An interviewee from an oil and gas company commented:

A lot of it [estimates] is guesswork, but it is very important to understand the viability of a company. It [Decommissioning] is a very, very complex and expensive process. You need a lot of cash to do it and its very labour intensive. This makes cost estimations with some reasonable confidence a huge challenge for us. It is basically guesswork.

Deputy Chief Finance Officer, Oil and Gas Company (O\&GI5).

These difficulties in estimating decommissioning costs, and therefore making appropriate provisions, is also evident in the accounting policies of oil and gas companies. For example:

The decommissioning of offshore infrastructure is a relatively immature activity and consequently there is limited historical precedent against which to benchmark estimates of future costs. These factors increase the complexity involved in determining accurate accounting provisions that are material to Shell's balance sheet. (Royal Dutch Shell Oil, Annual Report, 2015: 110).

Tullow Oil's policies also raise the same problems, thus:

Decommissioning costs are uncertain and cost estimates can vary in response to many factors, including changes to the relevant legal requirements, the emergence of new technology or experience at other assets. The expected timing, work scope, amount of expenditure and risk weighting may also change. Therefore significant estimates and 
assumptions are made in determining the provision for decommissioning. (Tullow Oil, Annual Report, 2015: 81)

These complexities are not only raised by the oil and gas companies, but also by regulators. For example, an interviewee from the Oil and Gas Authority (GOV3) pointed out that estimating decommissioning costs is a very complicated process and inaccuracies are bound to occur. These inaccuracies can have substantial implications for the company. For example, the company might have to re-state the cost provisions leading stakeholders, particularly the stock market, to lose confidence in the credibility of the company's information, with consequences for share prices and the cost of capital (see Healy and Palepu, 2001; Beyer et al., 2010).

The third complexity raised by nterviewees related to the fact that it takes many years before the assets are decommissioned, and in the interim, the law and accounting standards for decommissioning might change. ${ }^{6}$ Such changes have significant impact on the accuracy of the provisions that oil and gas companies make, and potentially influence how the company reports the information publicly. The problem with legislative changes was put forth eloquently by an oil and gas consultant interviewee (CONS1) stating:

At some point the government turns around and says, well actually, we did say we would give you relief, but actually we can't afford it and we are not going to give that relief in the future. How do you anticipate and capture such changes when estimating the costs? It's difficult.

Other challenges addressed by interviewees are: defining the point of cessation of production (GOV2); defining the timing for decommissioning (O\&GI1); identifying who will undertake the decommissioning process on behalf of the oil and gas company; defining the marginal oil price (O\&GI3); changes in regulations and taxation (CONS1; GOV1); instability of the exchange rates, technology, the actual cost of decommissioning and availability of finance to undertake decommissioning (CONS2; GOV1); changes of fields' ownership, subjectivity and uncertainty that affects budgeting for decommissioning. ${ }^{7}$

Taken altogether, these problems create concerns about the quality of the information, thus influencing oil and gas companies' decisions to provide sufficiently detailed information about the provisions for decommissioning costs. In particular, oil and gas companies perceive that disclosing greater information on decommissioning cost liabilities may exacerbate rather than

\footnotetext{
${ }^{6}$ This is also noted in the annual report of The Oil and Gas Development Company which states "Provision is based on the best estimates; however, the actual outflows can differ from estimated cash outflows due to changes in laws, regulations, public expectations, technology, prices and conditions, and can take place many years in the future. (Annual Report, 2015: 77)

7 The accounting policies of Europa Oil\&Gas states "By its nature, the detailed scope of work required and timing is uncertain" (Annual Report, 2015: 50). Similarly, the independent auditor's report of EnQuest Plc states "The decommissioning provisions are also affected by changes in the oil and gas reserve estimates and price assumptions which determine the date on which production will cease" (Annual Report, 2015: 80).
} 
reduce the information asymmetry problems between the company and its stakeholders. This view derives from the fact that because of the complexities in the estimations, stakeholders may not be able to process and understand the information, leading to misinterpretations. To this extent, oil and gas companies are concerned about the use of this information by stakeholders, thus reducing their incentives to commit to disclosing detailed information in the annual report. As expressed by one interviewee from an oil and gas company:

We tend not to put too much information in there that isn't required, because once you put something in there, it then gets a lot more scrutiny and people might not understand it.

Group Financial Controller, Oil and Gas Company (O\&GI1)

This may also be interpreted as oil and gas companies seeking to avoid setting a disclosure precedent that they may not be able to maintain in the future. For example, the assumptions relating to decommissioning costs may change drastically between periods due to changes to environmental conditions. Any change on disclosure as a result might then potentially be wrongly interpreted by stakeholders as indicative of major problems, creating difficulties for the company. This is consistent with Gibbins et al., (1990) and Graham et al. (2005), who both find out that managers attempt to avoid setting disclosure precedents as this would have economic implications for the company if not maintained.

\subsubsection{Factors influencing reporting decisions}

In the previous section, we examined the views of stakeholders on complexities and uncertainties in accounting for decommissioning costs. These were seen as major impediments to reporting detailed information about provisions for decommissioning costs in the annual reports. In this section, we draw insights from the disclosure literature (see Healy and Palepu, 2001 and Beyer et al., 2010 for reviews) and examine further factors that may affect a company's disclosure decisions. The disclosure literature argues that the decision to disclose information derives from the need to reduce information asymmetry between the company and its stakeholders. Such decisions are influenced by different factors such as regulations, agencyrelated costs, capital market pressures and proprietary costs. To understand these factors, we first explored interviewees' views on the current reporting practices of oil and gas companies in respect of provisions for decommissioning costs.

We find general agreement by the interviewees that the existing IAS reporting requirements for decommissioning costs are sufficient. The view of the interviewees is that the level of details to be provided must be left to oil and gas companies to decide voluntarily instead of via regulation. However, while regulators, academics and consultants were supportive of 
voluntary disclosure, they were critical about current reporting practices by oil and gas companies. In particular, they pointed out that the reporting practices of some oil and gas companies, for example providing a single numerical figure without detailed explanations, does not help understanding of decommissioning cost liabilities and the potential effects on the company's future cash flows. These views were echoed eloquently by an academic interviewee (ACA1):

Do I want to see pages and pages in an annual report? No, but there should be enough detail in there that shareholders and the analyst community can use to assess the liabilities of a company; like any other liability, if there is an outstanding contract dispute or there is another kind of legal liability they have, it should be explained, what the liabilities of the company are. Currently for decommissioning costs, this does not exist in annual reports.

A consultant interviewee (CONS2) also commented along similar lines:

With just one figure, it's very difficult for anyone to judge it from that one figure, you don't know how good the calculations are behind it [provisions for decommissioning costs], you don't know if everything is included, you don't know what assumptions have been made. That doesn't really help those interested in the information.

These views are consistent with the results of our content analysis phase, which demonstrated that there is no, or very little (if any), extra information in the annual reports to aid stakeholder understanding of some of the decommissioning cost figures reported. To this extent, oil and gas companies can be seen as failing to reduce the information asymmetry between the companies and shareholders, investors and other stakeholders. Interestingly, interviewees of oil and gas companies also agree that disclosure could be improved via voluntary rather than mandatory means. As one oil and gas company interviewee puts it:

I think in my mind they [IASs 16 and 37] provide enough. They cannot encompass every single possible item or detail. We still need interpretation and judgement, and reach a reasonable conclusion as to how much detail to give out. So, I would not be pushing for any new regulatory reporting requirements. No.

Integrated Planning and Appraisal Lead, Oil and Gas Company (O\&GI3)

This view reflects the belief that because the IAS/IFRS are principle-based standards, the oil and gas companies must be left to apply professional judgments in decisions as to whether they should provide information beyond minimum requirements. Despite this view, most oil and gas companies' disclosure strategy appears to focus on only providing the very minimum information required by accounting standards. Our analyses of the interviews suggest that this disclosure strategy stems from three key influential factors. First, in line with the work of Gibbins et al. (1990), it was clear that the oil and gas companies' attitude towards disclosure of 
information about provisions for decommissioning costs is driven by regulatory requirements. That is, their strategy is to just comply with the minimum disclosure requirements of IAS/IFRS, with no or little desire for voluntary and detailed disclosure. This position is summed up by a decommissioning compliance manager of a large oil and gas company (O\&GI2a):

Well, put it this way, from my own sitting, we disclose what we have to under GAAP. I think we do, if I'm being honest, the minimum disclosures we are required to do. We don't deliberately seek to disclose more or less than what is required in the annual reports. It comes down to the point of view that they [detailed disclosures] are not required to be honest. There is nothing that says that we [oil and gas companies] have to give any more information than we already do.

Given this adoption of a disclosure strategy that focuses on minimum compliance with mandatory requirements, it appears that if regulatory authorities, for example stock exchanges or accounting standard bodies, were to call for detailed disclosures to be provided in the annual reports, oil and gas companies would respond. Indeed, the interviewees expressed the desire to avoid negative consequences of non-compliance with disclosure requirements. As articulated by one interviewee, a deputy finance managers in an oil and gas company (O\&GI5):

It's [non-compliance] very costly, there are penalties, it's embarrassing for the board of directors, and you are misleading shareholders. It could be very embarrassing for the company, for the external auditors too.

Thus, as meeting regulatory disclosure requirements is particularly important for these companies, the opportunity for regulators to improve these disclosures exists. In fact, the detailed information already exists and provided, albeit confidentially, to the regulatory authorities such as the UK Oil and Gas Authority. As noted by a finance and legacy manager (O\&GI4) of one of the companies:

So, in [name of company] annual reports, you see decommissioning and restoration provisions actually combined with other provisions in the balance sheet. The breakdown of the provisions is provided to the UK government confidentially and the government aggregates it to produce an annual report, which talks about this $£ 40$ billion in decommissioning that they expect over the next 30 or 40 years. So, this gives people a guide but it doesn't give people the specifics, such as how much... [name of company] is spending on Brent Spar or on another asset.

This implies that companies could provide the information at no or little extra preparatory costs.

The second factor we identified relates to the demand for information by stakeholders such as investors, shareholders, environmental activist groups and the public at large. The literature suggests that because disclosure of information is costly (Verrecchia, 1990; Healy and Palepu, 2001), it will only be forthcoming when there is demand for the information by 
external stakeholders (see Gibbins et al., 1990). Such demand creates (dis)incentives for managers to disclose and reduce information asymmetry between stakeholders and the company. It was clear from our interviewees that demand for information by stakeholders was an important consideration for reporting information about provisions for decommissioning costs. In particular, the interviewees of oil and gas companies expressed the general view that stakeholders neither wanted nor understood the information about provisions for decommissioning costs. These views are exemplified in the following two comments:

I am not sure that the general public, investors, shareholders, and others, have a lot of awareness of it, really. If our Investor Relations people are saying to us, even the institutional investors don't seem all that bothered about it [decommissioning cost information], then you could argue that it's actually not that important to them.

Group Financial Accountant, Oil and Gas company (O\&GI2b)

and;

People rarely look at this or ... even ask for it, for example, analysts and shareholders. They don't ask you about all this stuff [provisions for decommissioning costs] ....., how you got to that and are you massaging, for example. They are looking at cash flows, they are looking at cash flow generation and they are looking at debts, if you have got any debts, and that's how they will assess your company. And that's why decommissioning, they will look at ours and say well you are not decommissioning anything until 2034. Not interested. Yes, I am not going to ask about that.

Deputy Chief Finance Officer, Oil and Gas Company (O\&GI5)

The basic view from the oil and gas companies is that if the information is not demanded by stakeholders, there is no need to expend costs to disclose it. Thus, even though the detailed information is already available in their information systems (as provided to regulatory authorities), the lack of stakeholder demand provides a disincentive to disclose it in annual reports. This is consistent with findings of Gibbins et al. (1990) that show that companies' disclosure strategy responds to external stimuli for disclosure. However, these views by the oil and gas companies are surprising and at odds with prior work on decommissioning cost information. For example, Khurana et al. (2001) provide evidence to show that provisions for decommissioning costs are value relevant for share valuations. This suggests that the capital market participants use the information for making investment decisions. To this extent, providing detailed disclosures of this information would help reduce information asymmetry between the company and capital markets. This reduction in information asymmetry would benefit the capital markets by providing better insights into the companies' financial positions and their ability to meet the obligations as they fall due and therefore give a better understanding of the implications for the future cash flows. 
The third and final factor brought out from the interviews, as affecting the disclosure of detailed information about provisions for decommissioning costs, relates to proprietary costs. According to the disclosure literature (see Dye, 1986; Verrecchia, 1990; Li et al., 1997), proprietary costs create incentives for companies to withhold information from stakeholders. The proprietary costs noted by our interviewees included increased public scrutiny, potential misinterpretation by users and release of strategic information. There was a uniformity of views relating to concerns about increased public scrutiny and the potential misinterpretation of information. The perceived effects of these two costs on the company were seen as particularly important in company decisions regarding the disclosure of information about provisions for decommissioning costs. A group accountant of an Oil and Gas Company (O\&GI2b) pointed out:

I am involved in the annual report and accounts process each year, and there are all sorts of considerations in terms of what level of information we put in there. We tend not to put too much in there that isn't required, because once you put something in there, it then gets a lot more scrutiny and, people might not understand it, might misinterpret it because it's complex, and there are implications for our share price, for our reputation.

From the oil and gas companies' perspective, increased scrutiny and misinterpretation arise because stakeholders cannot understand the complexities and uncertainties relating to the determination of provisions for decommissioning costs. As we noted earlier, the complexities and uncertainties in the estimation of decommissioning costs are, in the view of interviewees, too subjective to be relied on. To interviewees the capital markets, and stakeholders in general, may be concerned by the level of cost provisions even though their estimation is highly subjective. In particular, because stakeholders might view the high decommissioning cost provisions as indicative of the actual future cash outflows and the ability of the company to decommission, they may respond negatively to the information. This could have substantial effects on the company as it brings unnecessary public scrutiny and may harm the company's reputation. The issue of an ability to process information or misinterpretation of information is also raised in Kim and Verricchia (1994) and Coller and Yohn (1997) as creating further information asymmetries between the company and its stakeholders. Such misinterpretation affects share prices and the cost of capital of the company (Coles et al., 1995; Lambert et al., 2007; Cuadrado-Ballesteros et al., 2016). To this extent, these types of proprietary costs (i.e., public scrutiny and misinterpretation of information) play an important role in decisions by oil and gas companies to disclose information about provisions for decommissioning costs. 
Whilst the above might be true, these views by oil and gas companies also appear to contradict the disclosure literature in two ways. Firstly, from the perspectives of agency and signalling theories (Jensen and Meckling, 1976; Hughes, 1986), oil and gas companies should be publishing detailed information rather than just a single figure on provisions for decommissioning costs. Detailed disclosures would help clarify the amounts, thus allaying investor fears that managers may be concealing important information about the ability of the company to meet decommissioning obligations. This will reduce information asymmetry and improve liquidity of the company's shares leading to increasing share prices and, therefore, reducing the cost of capital (Hughes, 1986; Coles et al., 1995; see also Healy and Palepu, 2001 for a review). Secondly, oil and gas companies are already in the public eye due to the environmental impact of their operations (Li et al., 1997; Peters and Romi, 2013). As Li et al. (1997) argue, because of their operations, the legitimacy of oil and gas companies is always threatened. To this extent, one would expect these companies to increase information disclosure about provisions for decommissioning costs to inform stakeholders about their financial strength and preparedness to clean-up and remedy the environmental damage. This would reduce, rather than increase public scrutiny, as detailed information might change stakeholder perceptions about the company's operations. Consequently, we asked about this issue and the interviewees of oil and gas companies indicated that there are strategies other than disclosing information in an annual report by which they manage stakeholder perceptions. These involve well-coordinated engagement with the primary stakeholders. For these companies, the primary stakeholders include shareholders, investors, regulators, environmental groups and the public in general (see also Alciatore et al., 2004; Monciardini, 2016). As put forth by one interviewee:

I think for a project like Brent, which is obviously in the public eye, there is a whole stakeholder engagement process which is deliberate and very well-coordinated, to make sure that the project and the way it is being approached is properly understood by our stakeholders... This does not involve the annual report.

Integrated Planning and Appraisal Lead (O\&GI3)

This suggests that oil and gas companies may be engaging in private communications with their primary stakeholders about their plans and ability to decommission their assets when due. This appears to be consistent with Holland (1998) who found that companies engage in private disclosure in order to communicate some of their strategies rather than publicly disclosing the information in the annual reports. Thus, to the extent that the primary stakeholders are well- 
engaged and informed about the decommissioning costs and funding plans, they may not put pressure on oil and gas companies to publicly release the information in annual reports.

Finally, with regard to divulging confidential information, only two interviewees talked about decommissioning cost information as being of strategic importance. In particular, information on the cessation of production of any particular oil and gas field was considered as too confidential to publicly disclose as this is linked to the company's future prospects. Disclosing this type of information was seen as creating a competitive disadvantage for the company. The concern that releasing confidential information may hurt companies is welldocumented in the literature (see Bebbington et al., 2008; Beattie and Smith, 2012; McChlery et al., 2015). For example, among other things, potentially, disclosing the information may aid competitors in assessing the attractiveness of a particular oil and/or gas field or location, leading to new entrants (Ellis et al., 2012). This cost of disclosing information is exemplified in the quote by the finance manager of a large oil and gas company (O\&GI4):

Information about decommissioning can be strategic information, and companies don't want to disclose these too, in the public domain, and make it available for competitors. In particular, the one thing that has sensitivity specifically around it, in the way we turn an estimate into a balance sheet disclosed number, is the year that we are discounting back from, because obviously the cessation of production year is very confidential, and we don't want to disclose when we believe assets are ceasing production. There are lots of reasons, but it's people's jobs, it's the future of our company. I don't think we would make those disclosures easily public. Certainly, when we talk amongst industry groups that's something that we are all very conscious of.

Thus, divulging confidential information, competitive and otherwise, is an important factor influencing the disclosure of information about provisions for decommissioning costs in the annual reports of oil and gas companies.

\section{Conclusion}

In the context of the magnitude of decommissioning obligations in the oil and gas sector and the concern about the environmental impact of oil and gas companies, there have been growing calls for these companies to disclose more information about these obligations (see Standard and Poor's, 2007; Rogers and Atkins, 2015; Monciardini, 2016). In this study, we contribute to these calls by investigating compliance with international accounting standards' disclosure requirements relating to the provisions for decommissioning costs by oil and gas companies. Primarily, we examined the extent to which oil and gas companies comply with IASs 16 and 37 disclosure requirements. We also investigated the perception of selected key stakeholders on the reporting practices of oil and gas companies and the factors perceived as influencing 
such reporting practices. An understanding of compliance with mandatory disclosure requirements and reporting practices relating to provisions for decommissioning costs in general is of importance to regulators and other stakeholders. Thus, our findings have important implications for regulators in making decisions relating to the improvement of reporting of information for the benefit of stakeholders. In this case, given the reluctance by oil and gas companies to disclose detailed information, regulators might consider increasing the minimum disclosure requirements for provisions for decommissioning costs.

We find that the level of compliance with disclosure requirements was substantially high, with about $53 \%$ of oil and gas companies in our sample complying with over $70 \%$ of the requirements. However, what is evident is that full compliance is not achieved. More importantly, our analyses demonstrate that oil and gas companies appear to take a tick-box approach to compliance with IASs 16 and 37, providing the very minimum required information in the annual reports. In most cases, they provided only single numerical disclosure of provisions for decommissioning costs with no additional explanations to aid understanding. This practice appears to derive from the fact that IAS/IFRS are principle-based standards and require oil and gas companies to apply professional judgements in their interpretation and application. Nonetheless, we conclude that the current disclosure requirements need to be reconsidered to ensure that stakeholders are provided with relevant and detailed information about provisions for decommissioning costs of oil and gas companies.

We identified a number of reasons for the disclosure practice by the oil and gas companies. First, the complexities and uncertainties involved in the estimation of the provisions for decommissioning costs were identified as an important impediment to disclosure. In particular, the subjectivity by which the provisions are estimated raises concerns about the credibility of information conveyed to the stakeholders and how stakeholders might react to the information. Such concerns create a disincentive for disclosing the information by oil and gas companies. Second, disclosure of provisions for decommissioning costs was driven by regulatory requirements, that is the requirements of IASs 16 and 37. Companies were more focused on providing the minimum requirements with little or no extra disclosures. It was clear that in the absence of additional mandatory requirements, oil and gas companies were unwilling to provide detailed disclosures of decommissioning costs beyond that required by the accounting standards. Therefore, regualtors may need to consider improving the level of detail required to be disclosed by the oil and gas companies.

The third factor affecting disclosure decisions derives from the external demand for information. In this regard, the view of oil and gas companies was that because stakeholders 
did not demand the information on provisions for decommissioning costs, it was not necessary to disclose the detailed information. Thus, it appears that disclosure of provisions for decommissioning costs is not influenced by the desire to reduce information asymmetry voluntarily and reducing agency-related costs. Neither is it affected by incentives to signal to the capital market the quality of the company nor by reducing the cost of capital.

Finally, proprietary costs were also a major factor in the decision to report the information. In particular, oil and gas companies considered competitive disadvantage, information misinterpretation and increased public scrutiny as driving their disclosure strategies on provisions for decommissioning costs. The cost of misinterpretation of information and increased public scrutiny were major considerations.

Our findings must be interpreted in the context of a number of limitations. Although our sample is an improvement on prior studies, it is not substantially large and future studies can improve on the sample size. The number of companies included in the content analysis is limited to those that are listed on the LSE, and have decommissioning liabilities. However, these limitations are highlights for further research on the same topic that extends the sample to oil and gas companies listed on a number of international stock markets. Further studies on the users' satisfaction of the current disclosure practices of provisions for decommissioning oil and gas assets and demand for further disclosers is worth undertaking. 


\section{References}

Abdo, H. and Al Drugi, A., 2012. Do Companies' Characteristics Play Key Roles in the Level of their Environmental Disclosures? Energy Research Journal. 3(1), 1-11.

Abrahamson, J., 2014. Tolley's International Taxation of Upstream Oil and Gas. Second edition. LexisNexis. London.

Akerlof, G.A., 1970. The Market for 'Lemons': Quality Uncertainty and the Market Mechanism, Quarterly Journal of Economics, 84, 488-500.

Al Drugi, A. and Abdo, H., 2014. Determining the Motives or Reasons that Make Companies Disclose Environmental Information. Journal of Economics, Business and Management. 2(2), 117-121.

Alciatore, M., Dee, C.C. and Easton, P., 2004. Changes in environmental regulation and reporting: the case of the petroleum industry from 1989 to 1998, Journal of Accounting and Public Policy, 23, 295-304.

Al-Shammari, B; Brown, P; Tarca, A., 2008. An Investigation of compliance with international accounting standards by listed companies in the Gulf Co-Operation Council member states. International Journal of Accounting. 43(4), 425-447.

Barth, M.E., Landsman, W.R. and Lang, M.H., 2008. International accounting standards and accounting quality, Journal of Accounting Research. 46(3), 467-498

Beattie, V. and Smith, S. J., 2012. Evaluating Disclosure Theory Using the Views of UK Finance Directors in the Intellectual Capital Context. Accounting and Business Research. 42(5), 471-494.

Bebbington, J., Larringaga, C., Moneva, J. M., 2008. Corporate Social Reporting and Reputation Risk Management. Accounting, Auditing and Accountability. 21(3), 337-361.

Berry, K. T. and Wright, C. I., 2001. The Value Relevance of Oil and Gas Disclosures: an assessment of the market's perception of firms' effort and ability to discover reserves. Journal of Business Finance and Accounting, 28(5/6), 741 - 769.

Beyer, A., Cohen, D.A., Lys, T.Z. and Walther, B.R., 2010. The financial reporting environment: Review of the recent literature. Journal of Accounting and Economics. 50, 296-343.

Boatsman, J.R., Khurana, I.K. and Loudder, M.L., 2000. The economic implications of proposed changes in the accounting for nuclear decommissioning costs, Accounting Horizons, 14 92), 211-233.

Boone, J. P., 1998. Oil and gas reserve value disclosures and bid-ask spreads. Journal of Accounting \& Public Policy, 17(1), 55-84.

Coles, J., U. Loewenstein and Suay, J., 1995. 'On equilibrium pricing under parameter uncertainty', Journal of Financial and Quantitative Analysis, 30, pp. 347-364.

Coller, M. and Yohn, T., 1997. Management forecasts and information asymmetry: An examination of bid-ask spreads. Journal of Accounting Research, 35 (2), 181-191.

Collins, W., Davies, E.S. and Weetman, P., 1993. Management Discussion and Analysis: An Evaluation of Practice in UK and US Copanies. Accounting and Business Research. 23 (90): 123-137.

Cuadrado-Ballesteros, B; Garcia-Sanchez, I-M; and Ferrero. J. M., 2016. How are corporate disclosures related to the cost of capital? The fundamental role of information asymmetry. Management Decision. 54(7), 1669-1701.

D'Souza, J; Nash, R. C; Megginson, W. L., 2000. Determinants of Performance Improvements in Privatized Firms: The Role of Restructuring and Corporate Governance. AFA 2001 NEW Orleans. Amiable at: https://papers.ssrn.com/sol3/papers.cfm?abstract id=243186. Accessed on 06.05.2018 
Dye, R. A., 1986. Proprietary and non-proprietary disclosures, Journal of Business, 59(2), $331-366$.

Eisenhardt, K.M., 1989. Building theories from case study research, Academy of Management Review, 14 (4), 532-550.

Ellis, J.A., Fee E. and Thomas, S.E., 2012. Proprietary Costs and the Disclosure of Information About Customers, Journal of Accounting Research, 50 (3), 685-726.

Falconer, C. and Wicks, C., 2016. Decommissioning and the Offshore Oil and Gas Life Cycle. In: Hammerson and Antonas, N. 2016. Oil and Gas Decommissioning. 2nd Edition, Surrey. Globe Law and Business Limited.

Freeman, R.E., 1984. Strategic Management: A Stakeholder approach. Marshfield, MA: Pitman.

Gibbins, M., Richardson A.J. and Waterhouse J., 1990. The management of corporate financial disclosure: opportunism, ritualism, policies and processes. Journal of Accounting Research, 28 (1), 121-43.

Glaum, M. and Street, D. L., 2003. Compliance with the disclosure requirements of Germany's new market: IAS vs US GAAP. Journal of International Financial Management and Accounting. 14(1), 64-74.

Glaum, M., Schmidt, P., Street, D.L. and Vogel, S., 2013. Compliance with IFRS 3 and IAS 36 Required Disclosures Across 17 European Countries: Company and Country Level Determinants. Accounting and Business Research. 43 (3), 163-204.

Gosling, P., 2017. Accounting for decommissioning nuclear plants, ACCA Global, https://www.accaglobal.com/gb/en/member/member/accountingbusiness/2017/09/insights/nuclear-plants.html (accessed 9th July 2018).

Graham, J.R., Harvey, C.R. and Rajgopal, S., 2005. The economic implications of corporate financial reporting, Journal of Accounting and Economics, 40 (1/3), 3-73.

Hamzah, B. A., 2003. International rules on decommissioning of offshore installations: some observations. Marin Policy. 27, 339 - 348.

Healy, P.M. and Palepu, K.G., 2001. Information asymmetry, corporate disclosure, and the capital markets: a review of the empirical disclosure literature. Journal of Accounting and Economics, 31 (1/3), 405-440.

HM Revenue \& Customs., 2016. HMRC Annual Report and Accounts 2015-16. Available at: https://www.gov.uk/government/uploads/system/uploads/attachment_data/file/537876/ HMRC_Annual_Report_and_Accounts_2015-16-_print_pdf. Accessed on 23.09.2016.

Hodgdon, C; Tondkar, R. H; Adhikari, A; Harless, D. W., 2009. Compliance with International Financial Reporting Standards and Auditor Choice: new evidence on the importance of statutory audit. International Journal of Accounting, 44(1), 33-55.

Holland, J., 1998. Private disclosure and financial reporting, Accounting and Business Research, 28 (4), 255-269.

Hughes, P.J., 1986. Signalling by direct disclosure under asymmetric information, Journal of Accounting and Economics, 8, 119-142.

IAS 16., 2001. Property, Plant and Equipment. Available at: http://eifrs.ifrs.org/eifrs/PdfAlone?id=14483\&sidebarOption=UnaccompaniedIas. Accessed on 15.10.2015.

IAS 37., 2014., Provisions, Contingent Liabilities and Contingent Assets. Available at: http://eifrs.ifrs.org/eifrs/PdfAlone?id=14498\&sidebarOption=UnaccompaniedIas. Accessed on 14.10.2015.

Jensen, M.C. and Meckling, W.H., 1976. Theory of the firm: managerial behaviour, agency costs and ownership structure, Journal of Accounting and Economics, 3: 305-360.

Johansen, T. R. and Plenborg, T., 2013. Prioritising Disclosures in the Annual Reports. Accounting and Business Research. 43(6), 605-635. 
Khurana, I.K., Pettway, R.H. and Raman, K.K., 2001. The liability equivalence of unfunded nuclear decommissioning costs, Journal of Accounting and Public Policy. 20: 155-185

Kim, O and Verrecchia, R. E., 1994. Market liquidity and volume around earnings announcements. Journal of Accounting and Economics. 17(1-2), 41-67.

Lambert, R. C., C. L and Verrecchia, R., 2007. Accounting information, disclosure, and the cost of capital, Journal of Accounting Research. 45, 385-420.

Lee, M.C., Mucklow, B. and Ready, M.J., 1993. Spreads, Depths, and the Impact of Earnings Information: An Intraday Analysis, The Review of Financial Studies, 6 (2), 345-374.

Li, Y., Richardson, G.D. and Thornton, D.B., 1997. Corporate disclosure of environmental liability information: theory and evidence, Contemporary Accounting Research, 14 (3), 435-474.

Luther, R., 1996. The development of accounting regulation in the extractive industries: An international review. The International Journal of Accounting, 31 (1), 67-93.

Malone, D., Fries, C., and Jones, T., 1993. An Empirical Investigation of the Extent of Corporate Financial Disclosure in the Oil and Gas Industry, Journal of Accounting, Auditing and Finance, 8, 249-273.

Mangena, M and Pike, R., 2005. The Effect of Audit Committee Shareholding, Financial Expertise and Size on Interim Financial Disclosures. Accounting and Business Research. 35(4), 327-349.

McChlery, S., Kouhy, R., Paisey, C., Hussainey, K., 2015. An Empirical Study of the Determinants of UK Oil and Gas Voluntary Disclosures. Applied Economics. 47(54), 5917-5931.

Melville., A., 2011. International Financial Reporting: a practical guide. 3rd Edition. Prentice Hall. England.

Mitchell, R.K., Angle, B.R. and Wood, D.J., 1997. Toward a theory of stakeholder identification and salience: Defining the principle of who and what really counts. Academy of Management Review, 22, 853-886.

Monciardini, D., 2016. The coalition of the unlikely driving the EU regulatory process of nonfinancial reporting. Social and Environmental Accountability Journal, 36 (1), 76-89.

OIAC (Oil Industry Accounting Committee)., 2001. Statement of Recommended Practice (SORP). Accounting for Oil and Gas Exploration, Development, Production and Decommissioning Activities. Available at: http://oiac.co.uk/wpcontent/uploads/2015/05/SORP.pdf. Accessed on 16.10.2015.

Oil \& Gas Authority., 2018. Cost of UK Oil and Gas Decommissioning is Reducing. Press Release. Available at: https://www.ogauthority.co.uk/newspublications/news/2018/cost-of-uk-oil-and-gas-decommissioning-is-reducing/. Accessed on 07.08.208.

Parente, V., Ferreira, D., dos Santos, E.M. and Luczynsk, E., 2006. Offshore decommissioning issues: deductibility and transferability, Energy Policy, 34 (15), 1992-2001.

Peters, G.F. and Romi, A.H., 2013. Discretionary compliance with mandatory environmental disclosures: evidence from SEC filings, Journal of Accounting and Public Policy, 32, 213-236.

Picker., R; Clark., K; Dunn., J; Kolitz., D; Livne., G; Loftus., J; Van Der Tas., L., 2016. Applying IFRS Standards. 4th Edition. Wiley. Crnwall.

PWC., 2008. Financial Reporting in the Oil and Gas Industry. Available at: https://www.pwc.com/gx/en/energy-utilities-mining/pdf/ifrsog.pdf. Accessed on 28.01.2017.

Robinson, J.R., Xue, Y. and Yu, Y., 2011. Determinants of Disclosure Noncompliance and the Effect of the SEC Review: Evidence from the 2006 Mandated Compensation Disclosure Regulations, The Accounting Review, 86 (4), 1415-1444. 
Rogers, G. J. D. and Atkins, C., 2015. Environmental Disclosures Report Card: Oil and Gas Decommissioning Liabilities 2003-2014. Petroleum Accounting and Financial Management Journal. 34(3), 40-70.

Russell, A., Kouhy, R., Lyon, R. A., 1998. Accounting for the Abandonment of North Sea Oil and Gas Wells. ACCA Research Report No. 58, Certified Accountants Educational Trust, London.

Standard \& Poor's., 2007. Poor disclosure by Europe's Chemical, Oil \& Gas, and Metals \& Mining Companies Gives Limited Insight into Decommissioning and Environmental Provisions. Available at: http://www.endseurope.com/docs/70927b.pdf. Accessed on 25.04.2017.

Street, D. L. and Gray, S. J., 2001, Observance of International Accounting Standards: Factors Explaining Non-compliance, ACCA Research Report No. 74, Certified Accountants Educational Trust, London.

Techera, E. J and Chandler, J., 2015. Offshore installations, decommissioning and artificial reefs: Do current legal frameworks best serve the marine environment? Marine Policy. 59, 53-60.

Tower, G; Hancock, P; Taplin, R. H., 1999. A Regional Study of Listed Companies' Compliance with International Accounting Standards. Accounting Forum. 23(3), 293305.

Verrecchia, R.E., 1990. Information Quality and Discretionary Disclosure. Journal of Accounting and Economics. 12(4), 365-380.

\section{Companies Annual Reports and Accounts}

Empyrean Energy Plc, 2015

Europa Oil\&Gas, 2015

EnQuest Plc, 2015

The Oil and Gas Development Company, 2015

Rose Petroleum Plc, 2015

Royal Dutch Shell Oil, 2015

Tullow Oil, 2015 
Table 1: Sample of Oil and Gas Companies

\begin{tabular}{|c|c|c|}
\hline Total number of companies on both main LSE and AIM & & 122 \\
\hline Less: Companies with no revenues and no provisions & 40 & \\
\hline None exploration and production companies & 3 & \\
\hline Companies not engaged in oil or gas production & 11 & -53 \\
\hline Final number of companies in the sample & & 68 \\
\hline \multicolumn{3}{|l|}{ Sample Analysis: } \\
\hline \multicolumn{3}{|l|}{ 1. By Listing } \\
\hline Main Market & & 9 \\
\hline AIM & & 59 \\
\hline Total & & 68 \\
\hline \multicolumn{3}{|l|}{ 2. By country of origin } \\
\hline United Kingdom & & 17 \\
\hline Africa & & 7 \\
\hline Europe & & 5 \\
\hline Russia & & 7 \\
\hline South America & & 3 \\
\hline USA & & 7 \\
\hline India & & 5 \\
\hline Central Asia and Caspian & & 3 \\
\hline The Caribean & & 1 \\
\hline Mediterranean basin & & 1 \\
\hline Rest of the World & & 12 \\
\hline Total & & 68 \\
\hline
\end{tabular}


Table 2: List of interviewees

\begin{tabular}{|c|c|c|c|c|c|c|}
\hline Interview & Organisation & Code & Job Title & $\begin{array}{l}\text { Duration of } \\
\text { Interview }\end{array}$ & $\begin{array}{l}\text { Date of } \\
\text { Interview }\end{array}$ & $\begin{array}{l}\text { Mode of } \\
\text { Interview }\end{array}$ \\
\hline \multirow{2}{*}{1} & \multirow{2}{*}{ DBEIS } & GOV1a & $\begin{array}{c}\text { Head of Offshore } \\
\text { Decommissioning Unit }\end{array}$ & \multirow{2}{*}{28 minutes } & \multirow{2}{*}{16.05 .2016} & \multirow{2}{*}{ Telephone } \\
\hline & & GOV1b & $\begin{array}{c}\text { Senior Decommissioning } \\
\text { Manager }\end{array}$ & & & \\
\hline 2 & \multirow[t]{2}{*}{$\begin{array}{l}\text { Oil and Gas } \\
\text { Authority }\end{array}$} & GOV2 & $\begin{array}{c}\text { Infrastructure } \\
\text { Decommissioning } \\
\text { Manager UKCS }\end{array}$ & 30 minutes & 13.05 .2016 & Telephone \\
\hline 3 & & GOV3 & $\begin{array}{c}\text { Senior Accountancy } \\
\text { Advisor }\end{array}$ & 22 minutes & 23.05 .2016 & Telephone \\
\hline 4 & \multirow{6}{*}{$\begin{array}{l}\text { Oil and Gas } \\
\text { Industry }\end{array}$} & O\&GI1 & $\begin{array}{l}\text { Group Financial } \\
\text { Controller }\end{array}$ & 37 minutes & 21.06 .2016 & Telephone \\
\hline \multirow[b]{2}{*}{5} & & O\&GI2a & $\begin{array}{c}\text { Decommissioning } \\
\text { Compliance Manager }\end{array}$ & \multirow{2}{*}{32 minutes } & \multirow{2}{*}{ 10.06.2016 } & \multirow[b]{2}{*}{ Telephone } \\
\hline & & $\mathrm{O} \& \mathrm{GI} 2 \mathrm{~b}$ & $\begin{array}{l}\text { Group Financial } \\
\text { Accountant }\end{array}$ & & & \\
\hline 6 & & O\&GI3 & $\begin{array}{c}\text { Integrated Planning and } \\
\text { Appraisal Lead }\end{array}$ & 52 minutes & 16.05 .2016 & Telephone \\
\hline 7 & & O\&GI4 & $\begin{array}{c}\text { Finance and Legacy } \\
\text { Manager }\end{array}$ & 60 minutes & 05.05 .2016 & Telephone \\
\hline 8 & & O\&G I5 & $\begin{array}{c}\text { Deputy Chief Finance } \\
\text { Officer } \\
\end{array}$ & 40 minutes & 20.05 .2016 & Face-to-face \\
\hline 9 & \multirow[t]{2}{*}{ Academic } & ACA1 & $\begin{array}{l}\text { Chartered Accountant } \\
\text { and Academic Instructor }\end{array}$ & 25 minutes & 16.05 .2016 & Telephone \\
\hline 10 & & ACA2 & $\begin{array}{l}\text { Director of Oil and Gas } \\
\text { Institute }\end{array}$ & 25 minutes & 03.06 .2016 & Telephone \\
\hline 11 & \multirow{2}{*}{$\begin{array}{l}\text { Independent } \\
\text { Consultant }\end{array}$} & CONS1 & $\begin{array}{c}\text { Independent } \\
\text { Decommissioning } \\
\text { Consultant }\end{array}$ & 31 minutes & 15.06 .2016 & Telephone \\
\hline 12 & & CONS2 & $\begin{array}{c}\text { Independent } \\
\text { Decommissioning } \\
\text { Consultant } \\
\end{array}$ & 50 minutes & 25.05 .2016 & Face-to-face \\
\hline \multirow[b]{2}{*}{13} & \multirow[b]{2}{*}{ Auditor } & AUD1a & Partner & \multirow[b]{2}{*}{30 minutes } & \multirow[b]{2}{*}{16.06 .2016} & \multirow[b]{2}{*}{ Telephone } \\
\hline & & AUD1b & $\begin{array}{l}\text { Global Oil \& Gas } \\
\text { Assurance Leader }\end{array}$ & & & \\
\hline
\end{tabular}


Table 3: Results of content analysis-Descriptive statistics

\begin{tabular}{|c|c|c|c|c|}
\hline \multicolumn{5}{|l|}{ Panel A: Overall Disclosure Scores } \\
\hline & Mean & Std Dev & Minimum & Maximum \\
\hline \multicolumn{5}{|l|}{ Overall disclosure index: } \\
\hline All items & .634 & .243 & 0.00 & 1.00 \\
\hline With items 1 and 12 excluded & .711 & .269 & 0.00 & 1.00 \\
\hline \multicolumn{5}{|c|}{ Panel B: Distribution of Overall Disclosure Scores } \\
\hline Score range & \multicolumn{2}{|c|}{ All items included } & \multicolumn{2}{|c|}{ Items 1 and 12 Excluded } \\
\hline Score range & No of firms & $\%$ & No of firms & $\%$ \\
\hline 0 to under $50 \%$ & 14 & 20.5 & 13 & 19.1 \\
\hline $50 \%$ to under $60 \%$ & 8 & 11.8 & 1 & 1.5 \\
\hline $60 \%$ to under $70 \%$ & 10 & 14.7 & 8 & 11.8 \\
\hline $70 \%$ to under $80 \%$ & 18 & 26.5 & 10 & 14.7 \\
\hline $80 \%$ to $100 \%$ & 18 & 26.5 & 36 & 52.9 \\
\hline Totals & 68 & 100 & 68 & 100 \\
\hline
\end{tabular}


Table 4: Test for differences in disclosure compliance among companies: T-tests

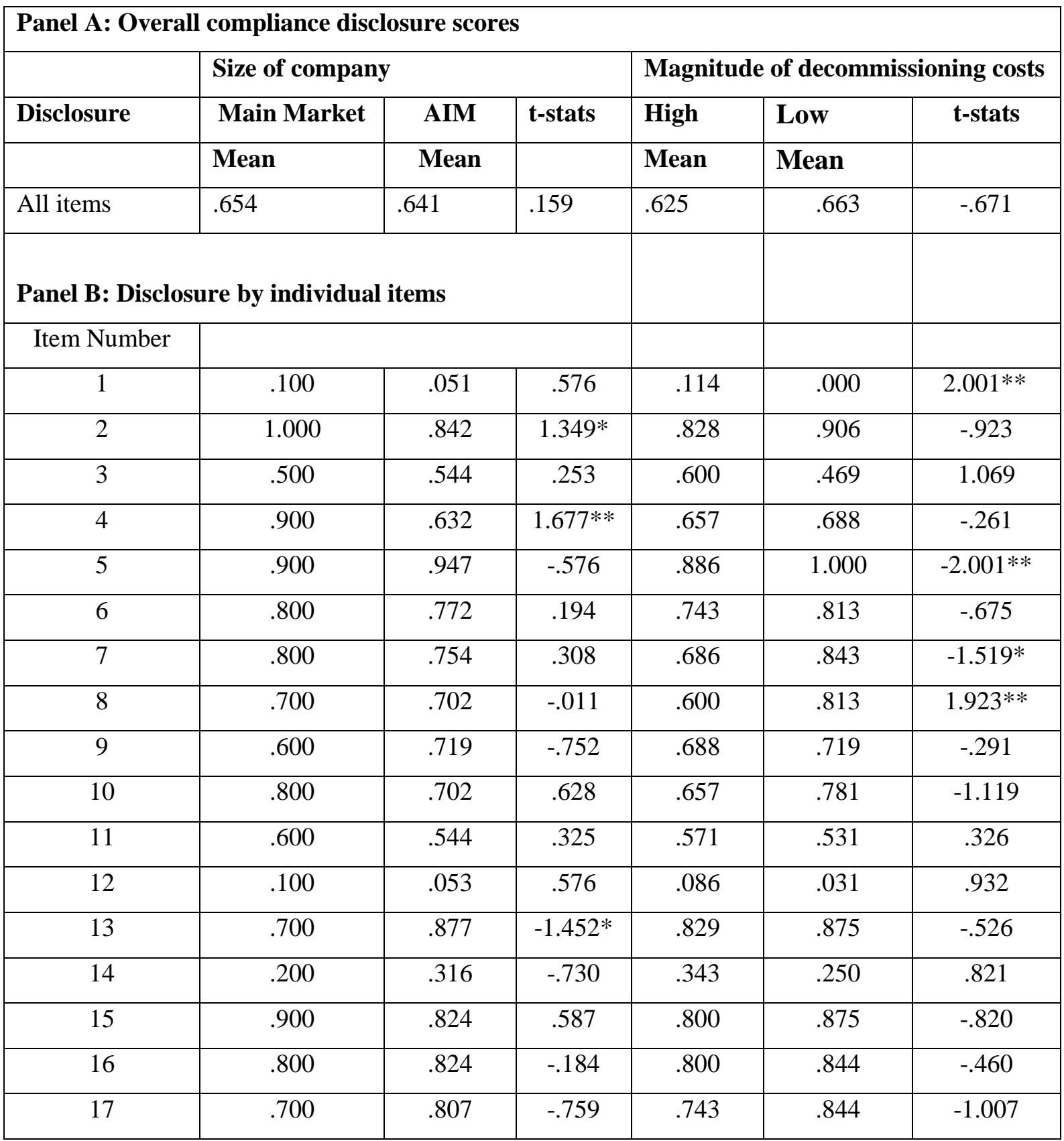

** Significant at the $5 \%$ level or better; * Significant at the $10 \%$ level or better 


\section{Appendix 1: Checklist}

\begin{tabular}{|c|c|}
\hline $\begin{array}{c}\text { Item } \\
\text { Number }\end{array}$ & Description \\
\hline & IAS37.25 requires that: \\
\hline 1 & $\begin{array}{l}\text { In the "extremely rare" cases where an entity cannot make a reliable estimate } \\
\text { of the future obligation and so cannot make a provision, the costs of } \\
\text { decommissioning should be treated as a contingent liability and the following } \\
\text { disclosed: } \\
\text {-A brief description of the of the nature of the contingent liability } \\
\text { Where practical } \\
\text { - An estimate of the financial effect measured under } \\
\text { - } \text { IAS37.36-52 } \\
\text { An indication of the uncertainties relating to the } \\
\text { - } \quad \text { The possibility of any reimbursement }\end{array}$ \\
\hline \multicolumn{2}{|r|}{ IAS37.45-47 requires that: } \\
\hline 2 & $\begin{array}{l}\text { Where the effect of the time value of money is material the provision should } \\
\text { be the present value of the expenditure required to settle the obligation }\end{array}$ \\
\hline 3 & $\begin{array}{l}\text { The discount rate used should be a "pre-tax rate (or rates) that reflect(s) } \\
\text { current market assessments of the time value of money and the risks specific } \\
\text { to the liability." }\end{array}$ \\
\hline \multicolumn{2}{|r|}{ IAS37.59 requires that: } \\
\hline 4 & $\begin{array}{l}\text { Provisions are revised annually to reflect the current best estimate of the final } \\
\text { provision }\end{array}$ \\
\hline \multicolumn{2}{|r|}{ IAS37.84 requires that for each class of provision an entity shall disclose: } \\
\hline 5 & the carrying amount at the beginning and end of the period \\
\hline 6 & $\begin{array}{l}\text { additional provisions made in the period, including increases to existing } \\
\text { provisions }\end{array}$ \\
\hline 7 & $\begin{array}{l}\text { amounts used (i.e. incurred and charged against the provision) during the } \\
\text { period }\end{array}$ \\
\hline 8 & unused amounts reversed during the period \\
\hline 9 & $\begin{array}{l}\text { the increase during the period in the discounted amount arising from the } \\
\text { passage of time and the effect of any change in the discount rate }\end{array}$ \\
\hline \multicolumn{2}{|r|}{ IAS37.85 requires an entity to disclose the following for each class of provision: } \\
\hline 10 & $\begin{array}{l}\text { A brief description of the nature of the obligation and the expected timing of } \\
\text { any resulting outflows of economic benefits }\end{array}$ \\
\hline
\end{tabular}




\begin{tabular}{|c|l|}
\hline 11 & $\begin{array}{l}\text { An indication of the uncertainties about the amount or timing of those } \\
\text { outflows. Where necessary to provide adequate information, an entity shall } \\
\text { disclose the major assumptions made concerning future events, as addressed } \\
\text { in paragraph 48 }\end{array}$ \\
\hline 12 & $\begin{array}{l}\text { The amount of any expected reimbursement, stating the amount of any asset } \\
\text { that has been recognised for that expected reimbursement }\end{array}$ \\
\hline 13 & $\begin{array}{l}\text { IAS16 requires the following: } \\
\text { be depreciated over the useful life of that asset }\end{array}$ \\
\hline 14 & $\begin{array}{l}\text { Disclosure of increase or decrease of assets due to adjustments of provisions } \\
\text { for decommissioning costs }\end{array}$ \\
\hline 15 & $\begin{array}{l}\text { IFRIC 1 requires the following: } \\
\text { The unwinding of the discount must be recognised in the P\&L as a finance } \\
\text { borrowing cost as defined in IAS23 and thus cannot be capitalised under that } \\
\text { standard [IFRIC 1.BC26-27] }\end{array}$ \\
\hline 16 & $\begin{array}{l}\text { Changes in the estimated cost of decommissioning through either a change in } \\
\text { the anticipated cash outflows or in the discount rate used should not be taken } \\
\text { to the P\&L as they occur, but should be recognised in the carrying value of } \\
\text { the related asset or in "other comprehensive income" depending upon } \\
\text { whether the asset is measured at cost or using the revaluation model. [IFRIC } \\
\text { 1.4-7] }\end{array}$ \\
\hline $\begin{array}{l}\text { Any significant increase in decommissioning costs should trigger an } \\
\text { impairment review [IFRIC 1.5] }\end{array}$ \\
\hline
\end{tabular}

